\title{
Analisis Framing Dugaan Korupsi Anas Urbaningrum dalam Kasus Wisma Atlet pada Harian Kompas dan Jawa Pos
}

\section{Tesa Herowana}

Alumnus Program Studi Ilmu Komunikasi

Universitas Islam Indonesia (UII), Yogyakarta

\section{Sumekar Tanjung}

Dosen Program Studi Ilmu Komunikasi

Universitas Islam Indonesia (UII), Yogyakarta

\begin{abstract}
In 2012, Indonesian Corruption Eradication Comission (KPK) investigate further to Nazaruddin statement about Anas Urbaningrum's corruption assessment on the sport center case. The frame analysis is used to look how Jawa Pos and Kompas Daily cover Anas Urbaningrum corruption assessment. This study concerns on Jawa Pos and Kompas Daily Januari editions 2012 about this news. It find that Jawa Pos Daily presents the Anas Urbaningrum's news with resolute. While Kompas Daily presents that news with irresolute.
\end{abstract}

Keywords: corruption, sport center case, framing analysis.

\begin{abstract}
Abstrak
Tahun 2012, Komisi Pemberantasan Korupsi (KPK) menginvestigasi pernyataan Nazarudin tentang korupsi yang dilakukan Anas Urbaningrum atas proyek pembangunan pusat olahraga. Analisis framing digunakan untuk melihat bagaimana harian Jawa Pos dan Kompas memberitakan kasus Anas Urbaningrum tersebut. Kajian ini mengambil sampel pemberitaan tahun 2012. Hasilnya, Jawa Pos memberitakan kasus Anas Urbaningrum dengan resolusi, sementara harian Kompas menyajikan berita tersebut tanpa resolusi.
\end{abstract}

Kata Kunci: korupsi, kasus Wisma Atlet, analisis framing.

\section{Pendahuluan}

Kasus Wisma Atlet ini terungkap saat terjadi penangkapan terhadap mantan bendahara Partai Demokrat tahun 2009 Muhammad Nazzarudin di Kolombia. Selama proses pengejaran, ia membeberkan semua hal yang terkait dengan kasus ini dalam wawancara kepada wartawan Independen melalui jaringan Skype.

Dalam wawancaranya, Nazaruddin memberikan pernyataan bahwa ia hanya akan menyerahkan diri jika KPK menangkap dalang dari semua kasus. Ia mengaku menyaksikan sendiri penyerahan uang dari PT Adhi Karya 
kepada Anas Urbaningrum sebagai imbalan telah membantu mendapatkan megaproyek pusat pendidikan dan pelatihan olah raga Hambalang, Kabupaten Bogor, Jawa Barat. Selain uang untuk Anas, PT Adhi Karya juga membagikan uang untuk politisi Partai Demokrat.

PT Dutasari Citralaras berperan dalam menampung upah atas megaproyek tersebut kemudian mengalokasikannya ke Menteri Pemuda dan Olahraga Andi Mallarangeng, Anas Urbaningrum, serta ke DPR. Proyek tersebut telah direncanakan sejak awal dalam rangka mendukung Anas untuk menjadi Ketua Umum Partai Demokrat.

Bahkan sang istri, Athiyyah Laila, sudah pernah diperiksa KPK. Pemeriksaan Athiyyah terkait posisinya sebagai mantan komisaris dan pemegang saham PT Dutasari Citralaras, perusahaan yang menjadi subkontraktor dalam proyek ini.

Selain itu, Anas diduga melakukan pertemuan dengan Dewan Pimpinan Cabang di beberapa hotel yang telah disepakati. Pemilihannya sebagai Ketua Umum Demokrat dari tahap ke tahap menghabiskan banyak dana untuk menyuap ke Dewan Pimpinan Cabang maupun anak buahnya. Sementara pada saat persidangan, Nazaruddin mengaku tidak pernah menerima uang satu rupiah pun dari APBN semenjak menjadi anggota DPR.
Pemberitaan dugaan kasus korupsi Anas Urbaningrum merupakan peristiwa penting. Peristiwa ini memenuhi hampir semua kriteria nilai layak berita. Nilai layak berita yaitu antara lain adalah penting (significane), besar (magnitude), waktu (timeliness), kedekatan (proximity), tenar (prominence) dan manusiawi (human interest). Salah satu nsur tersebut telah dapat menjadikan suatu kejadian layak diberitakan. Jika ditemukan lebih dari satu unsur, maka kejadian itu bertambah tinggi kelayakan beritanya, dan dianggap sebagai berita besar dan penting (Siregar 1998: 27-30).

Kasus ini merupakan masalah baru yang berhasil menggemparkan dunia politik, bahkan berpengaruh terhadap sektor-sektor lain seperti ekonomi budaya dan lain-lain. Tentu saja masalah korupsi sangat sulit diberantas karena harus dimulai dari akar terkecil yaitu diri manusia itu sendiri. Selain terbilang baru dan masih dalam tahap penyidikan, maka penelitian terdahulu mengenai kasus serupa belum peneliti temukan.

\section{Metode Penelitian}

Penelitian ini menggunakan metode analisis framing yang bertujuan untuk mendeskripsikan bagaimana frame kebijakan redaksional serta mengetahui sikap media cetak dalam membingkai pemberitaan tentnag dugaan korupsi Anas Urbaningrum. Dalam kajian praktis, penelitian ini berusaha untuk mengetahui 
bahwa media seharusnya tidak dipandang sebagai suatu institusi yang bebas dari nilai dan menyampaikan realitas secara apa adanya. Namun media adalah suatu institusi yang mempunyai berbagai macam kepentingan yang dalam mencapai kepentingan itu media melakukan berbagai macam konstruksi realitas.

Secara teoritis, penelitian ini diharapkan dapat memberikan kontribusi pemikiran bagi disiplin ilmu komunikasi. Dari sisi metodologis, penggunaan analisis framing di sini dapat menambah nuansa penelitian kualitatif mengenai isi media. Studi kualitatif dipandang mampu menyajikan kontribusi baik teoritis, metodologis dan perkembangan penelitian komunikasi yang bersifat interdisipliner.

Penelitian ini mengedepankan paradigma konstruktivisme yang melihat fenomena dugaan korupsi Anas Urbaningrum dapat ditanggapi, dimaknai dan dikonstruksi secara berbeda oleh tiap orang. Ini disebabkan karena tiap orang memiliki pengalaman dan lingkungan sosial tertentu, yang kesemuanya digunakan untuk menafsirkan realitas sosial yang ada di sekeliling dengan konstruksi masing-masing. Paradigma konstruktivisme yang masuk dalam kategori penelitian kualitatif ini mampu memberikan keleluasaan peneliti untuk melihat bagaimana media membingkai isu-isu yang berkaitan dengan dugaan korupsi Anas Urbaningrum.
Dalam pelaksanaannya, penelitian ini menggunakan metode analisis framing Pan dan Kosicki. Metode framing sendiri mengoperasikan empat dimensi strukstural teks berita sebagai perangkat framing yaitu sintaksis, skrip, tematik dan retoris (Sobur, 2002: 174). Sintaksis merupakan skema berita yang menghubungkan dengan bagaimana wartawan menyusun peristiwapernyataan, opini, kutipan, pengamatan atau peristiwa dalam bentuk berita. Sintaksis bisa diamati dari bagan berita yakni headline, lead, latar belakang informasi, dan lainnya. Adapun dimensi skrip menggambarkan bagaimana wartawan mengemas peristiwa atau bagaimana wartawan bercerita dengan melihat kelengkapan unsur $5 \mathrm{~W}+1 \mathrm{H}$ sebagaimana dalam hukum komunikasi tersebut.

Subjek yang diteliti adalah keseluruhan unit analisis yang akan diteliti (populasi) dalam penelitian ini, yakni pemberitaan dugaan korupsi Anas Urbaningrum pada Harian Kompas dan Jawa Pos edisi Januari 2012, dengan asumsi bahwa pada rentang waktu tersebut pemberitaan terkait dugaan korupsi Anas Urbaningrum makin intensif.

\section{Tinjauan Pustaka}

Teori yang mendasari penelitian ini merujuk pada yang dikemukakan oleh Peter L. Berger dan Thomas Luckman 
tahun 1966 (dalam Bungin, 2007: 191). Yang mendeskripsikan bahwa proses sosial melalui tindakan dan interaksinya, yang mana individu menciptakan secara terus menerus suatu realitas yang dimiliki dan dialami bersama secara subjektif. Mereka memulai penjelasan tentang realitas sosial dengan memisahkan antara oemahaman "kenyataan" dan “pengetahuan”. Realitas diartikan sebagai kualitas yang terdapat di dalam realitasrealitas yang diakui memiliki keberadaan (being) yang tidak tergantung kepada kehendak kita sendiri. Sedangkan pengetahuan didefinisikan sebagai kepastian bahwa realitas-realitas itu nyata dan memiliki karakteristik yang spesifik.

Kekuatan media sebagai saluran untuk mempengaruhi khalayak telah memberikan andil dalam pembentukan opini public. Bahkan dalam komunikasi politik, media menjadi penggerak utama dalam usaha mempengaruhi perilaku individu terhadap exposure berita yang diterimanya. Maka penggunaan media dalam proses politik tertentu memiliki arti yang sangat penting, begitu pula dampak dari penyebaran pesan terhadap khalayak luas akan terjadi secara kuat, apalagi dilihat dari dampak penyebaran pesan tidak hanya sampai pada tahap kognitif dan afektif tetapi juga sampai pada tahap konatif.

Kini isu korupsi telah begitu memberikan pengaruh besar kepada masyarakat Indonesia. Setiap orang dapat melakukan korupsi dan tidak terkecuali.
Ini pada dasarnya dipengaruhi oleh kebiasaan dan adanya kesempatan serta keinginan seseorang untuk melakukan korupsi. Hal ini juga telah berkembang ke sektor komunikasi, khusunya media. Didalam kehidupan, media massa telah menjadi bagian yang penting, manusia membutuhkan media untuk mengetahui segala sesuatu yang sedang terjadi di sekitarnya. Hal ini dapat diperoleh dari media. melalui bekal informasi, setiap orang dapat turut berpartisipasi di dalam kehidupan bermasyarakat. Untuk mendapatkan kepastian informasi itu, setiap orang membutuhkan wartawan surat kabar yang bertugas sebagai wakil masyarakat untuk mencari dan memberi tahu tentang segala peristiwa yang terjadi yang dibutuhkan masyarakat. Pada sisi inilah, mengapa wartawan memiliki hak untuk mengetahui segala informasi publik, dan diberi keleluasaan untuk mencari ke mana pun informasi itu berada.

Model analisis framing yang paling populer adalah Pan dan Kosicki. Menurut Eriyanto (2002: 251), dalam hal ini terdapat dua konsepsi framing yang saling berkaitan, yaitu konsepsi psikologis dan konsepsi sosiologis. Dalam konsepsi psikologis, framing dilihat sebagai penempatan informasi dalam suatu konteks khusus dan menempatkan elemen tertentu dari suatu isu dengan penempatan lebih menonjol dalam kognisi seseorang. Elemen-elemen yang diseleksi itu menjadi lebih penting dalam 
mempengaruhi pertimbangan seseorang saat membuat keputusan tentang realitas. Jadi, konsepsi psikologis lebih menekankan pada bagaimana seseorang memproses informasi dalam dirinya. Sedangkan dalam konsepsi sosiologis framing dipahami sebagai proses bagaimana seseorang mengklasifikasikan, mengorganisasikan, dan menafsirkan pengalaman sosialnya untuk mengerti dirinya dan realitas di luar dirinya.

Kedua konsepsi tersebut diaplikasikan pada proses mencari tahu bagaimana sebuah peristiwa dikonstruksi oleh wartawan dan bagaimana berita atas peristiwa tersebut diproduksi. Ada tiga hal dalam proses produksi berita yang dapat dikaitkan dengan konsepsi psikologis dan sosiologis. Yang pertama adalah proses konstruksi atas peristiwa atau realita melibatkan nilai-nilai sosial yang melekat dalam diri seorang wartawan. Yang kedua, ketika menulis dan mengkonstruksi berita, wartawan pasti mempertimbangkan kondisi khalayak yang akan membaca beritanya. Yang ketiga, proses konstruksi sebuah peristiwa juga ditentukan oleh standar kerja, profesi jurnalistik, dan standar profesional dari wartawan.

\section{Hasil dan Pembahasan}

Berikut merupakan simpulan atas temuan-temuan yang peneliti lakukan atas pemberitaan dugaan korupsi Anas
Urbaningrum dalam Harian Kompas dan Jawa Pos edisi Januari 2012.

\section{a. Temuan terhadap Harian Kompas}

Kasus Dugaan Korupsi yang dilakukan oleh Anas Urbaningrum ini merupakan peristiwa yang menjadi perhatian besar awak media. Terutama karena kasus ini menyangkut nama-nama besar yang saat ini masih menjabat sebagai petinggi dipemerintahan negara maupun di partai politik khususnya Partai Demokrat. Penyajian berita menggunakan piramida terbalik dengan maksud mendahulukan hal yang sangat penting (klimaks) dari peristiwanya. Selanjutnya diikuti oleh hal-hal yang penting, dan diakhiri oleh hal-hal yang kurang atau tidak penting. Keseluruhan struktur naskah berita terdiri dari tiga unsur yaitu headline (judul berita), lead (teras berita), dan body (kelengkapan atau penjelasan berita).

Headline yang dibuat oleh Harian Kompas cukup relevan dengan teori yang disampaikan di atas bahwa headline berfungsi memanggil khalayak agar mau membaca, mendengar ataupun menonton beritannya. Penulisan headline di Harian Kompas telah berhasil memberikan intisari dari peristiwa yang diberitakan. Headline yang dibuat oleh harian Kompas menurut peneliti, rata-rata sudah memenuhi kriteria sebagai Judul dan sudah relevan dengan apa yang telah disampaikan di atas bahwa headline berfungsi u ntuk memanggil khalayak agar 
mau membaca, mendengar, ataupun menonton beritanya. Contohnya adalah pada berita harian Kompas pada tanggal 31 Januari 2012 yang berjudul "Anas Dinilai Masih Kuat", ada sebuah daya tarik bagi pembaca, pembaca disini yang di maksud adalah pembaca yang telah mengikuti kasus ini.

Pembaca yang telah mengkuti alur cerita sebelumnya atau setidaknya telah memiliki pengetahuan tentang ini pasti akan tertarik karena Harian Kompas berani menulis berita tentang kekuatan politik yang dimiliki oleh Anas Urbaningrum. Kekuatannya ini masih memiliki pengaruh yang besar sehingga hingga saat ini ia masih belum dijadikan tersangka dan masih menjabat sebagai Ketua Umum Partai Demokrat. Tetapi hal ini tidak akan berlaku pada pembaca yang awam, mereka tidak akan cukup mengerti apabila hanya membaca judul yang disebutkan tadi.

Selanjutnya, Harian Kompas kurang memahami pengertian lead berita secara mendalam, bahkan ada beberapa berita yang kurang jelas dalam penyampaiannya, sehingga khalayak sulit untuk memahami isi berita yang akan disampaikan. Di dalam penyampaiannya, Harian Kompas juga memasukkan opini di dalam lead yang di sampaikan, hal ini termasuk di dalam berita tanggal 31 Januari 2012 yang berjudul "Anas Dinilai Masih Kuat", di dalamnya disebutkan kemungkinan Anas Urbaningrum sebagai Ketua Umum Partai Demokrat untuk dilengserkan, tetapi wartawan yang menulis berita tersebut mengatakan bahwa mungkin Anas Urbaningrum sudah dimundurkan dari jabatannya jika ia tidak memiliki pendukung yang kuat.

Contoh bagian body berita, Harian Kompas menyampaikan berita berjudul "Ketua Besar Berinisial MA" (12 Januari 2012). Dalam body berita, Harian Kompas menjelaskan bahwa pengacara dari Ketua Umum DPP Partai Demokrat Anas Urbaningrum, Patra M Zein memberikan pernyataan bahwa pihaknya tidak terlalu menanggapi tudingan terkait keterlibatan kliennya. Dengan piramida terbalik, seharusnya berita disusun berdasarkan info paling penting, kemudian ke info yang tidak penting. Namun, berita yang di tulis oleh wartawan Harian Kompas ini tidak menunjukkan info yang sangat penting. Seharusnya apabila beritanya berjudul "Ketua Besar Berinisial MA", wartawan Harian Kompas seharusnya menerangkan tentang siapakah yang akan membeberkan berita tersebut dan kaitannya dengan persidangan yang tertunda.

Di dalam paragraf selanjtnya terjadi pengulangan isi berita yang menyebutkan bahwa pihak Anas Urbaningrum tidak terlalu menanggapi tuduhan yang selama ini di tujukan kepada kliennya. Seharusnya wartawan Harian Kompas menulis berita yang lebih singkat dan penting sehingga khalayak ataupun pembaca dapat memahami berita yang disampaikan secara tepat. 
Laporan Berita sering disusun sebagai suatu cerita, hal ii karena dua hal. Pertama, banyak laporan berita yang berusaha menunjukkan hubungan, peristiwa yang ditulis merupakan kelanjutan dari peristiwa sebelumnya. Kedua, berita umumnya memiliki orientasi menghubungkan teks yang ditulis dengan lingkungan komunal pembaca. Bentuk umum dari struktur skrip ini adalah pola $5 \mathrm{~W}+1 \mathrm{H}$ (who, what, when, where, why dan how). Meskipun pola ini tidak terlalu dapat dijumpai dalam setiap berita yang ditampilkan, kategori informasi ini yang diharapkan diambil oleh wartawan untuk dilaporkan (Eriyanto, 2002: 260).

Pada pemberitaan Harian Kompas pada tanggal 27 Januari 2012, berjudul “Jika Tersangka, Dicopot". Semua unsur berita dijelaskan dalam berita ini. Tetapi ada satu unsur berita yang tidak dijelaskan pada berita ini yaitu, unsur where, yaitu tempat dilakukan wawancara yang dilakukan oleh wartawan Harian Kompas pada saat mewawancarai Ketua Dewan Pimpinan Pusat Patai Demokrat Sutan Bathoegana. Khalayak tidak mengetahui secara pasti dimana mereka melakukan wawancara, hanya diberikan keterangan pada awal lead yang berituliskan kota Jakarta dan tidak menulis secara lengkap dimana wawancara dilakukan. Padahal menurut teori di atas, kategori informasi dari unsur $5 \mathrm{~W}+1 \mathrm{H}$ ini diharapkan dapat dijelaskan secara lengkap oleh wartawan Harian
Kompas. Unsur where seharusnya bisa memberikan informasi tempat dimana wawancara dilakukan. Pada kenyataannya Harian Kompas tidak menjelaskan di mana berlangsungnya wawancara, padahal itu merupakan salah satu unsur yang bisa menjawab unsur-unsur lain.

Dalam menulis berita, seorang wartawan mempunyai tema tertentu atas suatu peristiwa. Ada beberapa elemen yang dapat diamati dari perangkat tematik ini. Diantaranya adalah koherensi, yakni pertalian atau jalinan antarkata, proposisi yang menggambarkan fakta yang berbeda dapat dihubungkan dengan menggunakan koherensi. Sehingga fakta yang tidak berhubungan sekalipun dapat menjadi berhubungan ketika seseorang menghubungkannya (Eriyanto, 2002: 262-263).

Sebagai contoh, berita "El Idris Mencabut Keterangan di BAP” di Harian Kompas tanggal 19 Januari 2012. Dalam berita ini terdapat dua tema yang diangkat oleh wartawan Harian Kompas. Tema yang utama adalah Pencabutan keterangan saksi di Berita Acara Pengadilan kasus wisma atlet. Tema yang kedua adalah Partai Demokrat memilih untuk menunggu proses hukum kadernya. Tema yang pertama menjelaskan bahwa Mohammad El Idris, Manajer PT Duta Graha Indah telah mencabut keterangan terkait komitmen atas fee dalam proyek pembangunan Wisma Atlet SEA Games. Tema yang kedua adalah Partai Demokrat memilih untuk menunggu proses hukum 
kasus wisma atlet, kadernya yang disebut dalam pengadilan diperingati untuk lebih berhati-hati.

\section{Penjelasan Harian Kompas} tersebut sesuai dengan teori yang telah dijelaskan di atas. Harian Kompas ingin mengangkat semua peristiwa sehingga menjadi berita yang saling berhubungan. Pada kenyataannya Harian Kompas mengangkat tema lain yang masih berhubungan dengan tema utama, yaitu pencabutan keterangan Mohammad El Idris di BAP. Tema utama memiliki hubungan terhadap tema kedua yaitu sama-sama masih membicarakan tentang kasus wisma atlet. Harian Kompas berhasil menggabungkan kedua tema tersebut sehingga terdapat koherensi sehingga kedua tema dapat dihubungkan. Koherensi yang dipakai adalah digunakannya kalimat "Terkait terseretnya kader Partai Demokrat dalam kasus wisma atlet, Partai demokrat memilih menunggu proses hukum kasus itu." Dalam pemberitaan ini tema utama berhasil diangkat informasinya lebih banyak daripada tema kedua. Intinya tema utama lebih mendominasi pemberitaan. Harian Kompas bisa dikatakan berhasil mengangkat tema yang sesuai.

Pada berita tanggal 26 Januari 2012 yang berjudul "Yulianis: Tercatat Ada Uang ke Anas", Harian Kompas menggunakan elemen grafis yang memuat gambar-gambar atau ilustras dari peristiwa yang berhubungan dengan dugaan korupsi yang dilakukan oleh Anas Urbaningrum. Dalam sidang kasus wisma atlet, gambar yang di muat adalah gambar wajah serta nominal uang yang diduga mengalir kepada orang-orang yang tercantum pada gambar. Di dalam elemen grafis yang berupa ilustrsi ini terdapat lima orang yang disebut oleh Yulianis, yaitu I Wayan Koster, Anggota DPR yang disebut telah menerima uang sebesar 3 Miliar Rupiah, Angelina Sondakh Anggota DPR diduga menerima uang sebesar 2 Miliar Rupiah, Paul Nelwan, seorang pengusaha, orang kepercayaan Wafid Muharam disebut menerima uang sebesar 150 Juta Rupiah, Andi Malarangeng, seoran Menteri Pemuda dan Olahraga, disebut menerima 150 Juta Rupiah dan Anas Urbaningrum, Ketua Umum Parta Demokrat yang disbeut oleh Yulianis telah menerima uang sebesar 150 Juta Rupiah.

\section{Dalam Berita Harian Kompas} tanggal 12 Januari 2012 yang berjudul "Ketua Besar Berinisial MA", elemen grafis yang ditampilkan adalah sebuah kolom yang berisi gambar kepala Muhammad Nazaruddin dan disebelahnya terdapat nama-nama yang disebut telah menerima uang korupsi Wisma Atlet. Didalam kolom tersebut terdapat lima orang yang disebut oleh Muhammad Nazaruddin telah menerima uang korupsi. Diantaranya adalah Anas Urbaningrum, Angelina Sodakh, Andi Malarangeng, Mirwan Amir, dan I Wayan Koster. Kelima nama itu telah disebut oleh Muhammad Nazaruddin telah menerima uang korupsi 
wisma atlet. Elemen grafis yag di muat oleh Harian Kompas tersebut digunakan untuk meringkas apa yang telah ditulis oleh Wartawan untuk memperjelas atau mempertegas siapa saja yang disebut telah terlibat kasus korupsi wisma atlet ini.

Praktik jurnalistik secara teknis dalam peliputan berita memiliki nilai berita. Agar berita memiliki nilai tertinggi ada empat faktor utama, yaitu ketepatan waktu (timeliness), kedekatan tempat kejadian (proximity), besarnya (size), kepentingan (importance) (Suhandang, 2004: 144-145). Contoh dalam hal ketepatan waktu, Harian Kompas sebagian besar telah menerangkan akurasi waktu antara peristiwa dengan waktu terbit koran. Pada saat memuat berita, Harian Kompas selalu memberikan tanggal kapan kejadian yang diberitakan tersebut berlangsung. Dengan begitu pembaca dapat mengetahui kapan berita itu di buat dan kapan berita di cetak. Harian Kompas telah memberitakan secara jelas tanggal berapa waktu kejadiannya sehingga antara waktu cetak koran dengan peristiwa memiliki kedekatan waktu yang tidak terlalu jauh dan berita tidak dianggap basi.

Jika dilihat dari kedekatan tempat kejadian, kantor pusat Harian kompas berada di wilayah Jakarta di mana persidangan kasus yang diduga melibatkan Anas Urbaningrum dilakukan. Kedekatan ini telah membuat Harian Kompas selalu mengikuti perkembangan yang menyangkut kasus ini. Terbukti dari jumlah berita yang dimuat oleh Harian Kompas dalam kurun waktu satu bulan. Pada bulan Januari 2012 sendiri terdapat 15 berita yang diberitakan.

\section{b. Temuan terhadap Harian Jawa Pos}

Headline pada berita tanggal 26 Januari 2012, "Yulianis Beber Money Politics Anas". Menurut peneliti judul ini memiliki daya tarik bagi pembaca, hal ini dikarenakan adanya keterangan bahwa Anas Urbaningrum disebut oleh saksi yang dalam hal ini adalah Yulianis, telah menerima uang suap. Apabila kasus ini dikembangkan lagi, bukan tidak mungkin Anas Urbaningrum yang sampai saat ini masih tidak tersentuh oleh hukum tersebut berubah menjadi seorang tersangka yang akan diadili.

Selanjutnya, Harian Jawa Pos telah berhasil memahami pengertian dari lead secara mendalam, terbukti didalam berita yang telah diterbitkan tersebut banyak berita yang memiliki lead yang mudah dimengerti oleh pembaca. Sebagai contoh, beberapa isi dari berita yang sesuai dengan lead berita yaitu pada berita yang berjudul "Dewan Pembina Sudah Bahas Pengganti Anas” tanggal 31 Januari 2012. Pada berita ini lead yang di gunakan adalah serapat apapun rahasia yang dimiliki oleh Partai Demokrat, tetap saja pada akhirnya publik akan mengetahuinya. Lead yang ditulis oleh Harian Jawa Pos sesuai dengan teori 
yaitu lead yang bisa memenuhi rasa ingin tahu penontonnya.

Contoh bagian tubuh berita, Harian Jawa Pos menyampaikan berita berjudul "Wacana Pengganti Anas Sudah Muncul” (26 Januari 2012). Dalam body berita, Harian jawa Pos menjelaskan bahwa berita tentang adanya rencana penggantian Anas Urbaningrum sebagai ketua umum Partai Demokrat. Degan piramida terbalik, berita telah disusun berdasarkan info paling penting, ke info penting, kemudian info yang tidak penting. Berita yang dicantumkan oleh Harian Jawa Pos menunjukkan info yang sangat penting. Berita yang dimuat juga sudah memiliki klimaks peristiwanya.

Isi berita pada mulanya menceritakan bahwa posisi Anas Urbaningrum sebagai ketua umum Partai Demokrat sudah tidak aman karena dianggap telah merusak citra Partai Demokrat. Menurut salah seorang petinggi Partai Demokrat menyebutkan bahwa mereka ingin membicarakan masa depan Partai Demokrat agar lebih baik pada masa berikutnya. Harian Jawa Pos mengemas berita dengan kemasan yang rata-rata sama. Wacana penggantian Anas, siapa penggantinya, dan pembelaan Anas Urbaningrum menanggapi tuduhantuduhan yang ada.

Pada berita tanggal 29 Januari 2012, berjudul "Nasib Anas Bergantung T.B. Silalahi”, semua unsur berita dijelaskan dalam berita ini. Tetapi ada satu unsur berita yang tidak dijelaskan pada berita ini yaitu unsur where, yaitu tempat dilakukannya wawancara, pada berita tersebut, wartawan Harian Jawa pos hanya menyebutkan bahwa wawancara ini terjadi pada saat diskusi di Jakarta dan tidak menyebutkan secara terperinci bahwa apakah diskusi yang di maksud adalah diskusi internal parta atau diskusi antara wartawan dengan narasumber. Padahal menurut teori di atas, kategori informasi dari insur $5 \mathrm{~W}+1 \mathrm{H}$ ini diharapkan dapat dijleaskan secara lengkap oleh wartawan Harian Jawa Pos.

Dalam menulis berita, seorang wartawan mempunyai tema tertentu atas suatu peristiwa. Dengan pengambilan tema tersebut tentu saja telah diperhitungkan koherensi terhadap tema lainnya. Sebagai contoh, berita "Yulianis Beber Money Politics Anas”. Dalam berita ini terdapat dua tema yang diangkat oleh wartawan Harian Jawa Pos. Tema yang utama yaitu kesaksian Yulianis, mantan wakil direktur keuangan grup permai yang mulai membeberkan keterlibatan Anas Urbaningrum. Tema yang kedua adalah reaksi dari Nazaruddin setelah anak buahnya, Mindo Rosalina Manulang ditangkap oleh KPK.

Tema yang pertama menjelaskan bahwa Yulianis telah memberikan kesaksian bahwa Anas Urbaningrum telah menggunakan money politics guna melancarkan ambisinya menjadi ketua umum Partai Demokrat. Tema yang kedua merupakan tema tambahan yang diberikan oleh wartawan Harian Jawa Pos 
untuk menguatkan tema utama perihal reaksi yang terjadi pada saat Nazaruddin mengetahui bahwa anak buahnya sudah ditangkap oleh KPK. Dari penjelasan Harian Jawa Pos tersebut sesuai dengan toeri yang telah dijelaskan sebelumnya di atas. Harian Jawa Pos ingin mengangkat semua peristiwa sehingga menjadi berita yang saling berhubungan.

Struktur retoris dari wacana berita menggambarkan pilihan gaya atau kata yang dipilih oleh wartawan untuk menekankan arti yang ingin ditonjolkan oleh wartawan. Wartawan menggunakan perangkat retoris untuk membuat citra, meningkatkan kemenonjolan pada sisi tertentudan meningkatkan gambaran yang diinginkan dari suatu berita. Struktur retoris dari wacana berita juga menunjukkan kecenderungan bahwa apa yang disampaikan tersebut adalah suatu kebenaran. Ada beberapa elemen struktur retoris yang dipakai oleh wartawan. Elemen grafis juga muncul dalam bentuk foto, gambar, dan tabel untuk mendukung gagasan atau untuk bagian lain yang tidak ingin ditonjolkan (Eriyanto, 2002: 264266).

Pada berita, Harian Jawa Pos menggunakan elemen grafis yang menampilkan gambar-gambar dari peristiwa yang berhubungan dengan dugaan korupsi yang dilakukan oleh Anas Urbaningrum dalam kasus wisma atlet. Dalam memberitakan kasus ini, Harian Jawa Pos menyisipkan elemen grafis yang sesuai dan mendukung tema utama berita.
Misalnya dalam berita yang berjudul "Yulianis Beber Money Politics Anas" tanggal 26 Janauari 2012. Dalam berita ini menjelaskan bahwa Yulianis, mantan wakil direktur keuangan Grup Permai, telah membeberkan money politics yang dilakukan oleh Anas Urbaningrum serta menyebutkan beberapa nama pejabat lain yang terlibat kasus ini. Untuk mendukung gagasan utama dari berita ini, Harian Jawa Pos menyisipkan gambar dari empat orang yang disebut memiliki peran yang penting didalam kasus korupsi ini. Gambar yang ditampilkan adalah gambar dari Anas Urbaningrum, Andi Malarangeng, Muhammad Nazaruddin, dan Yulianis. Keempat gambar tersebut disertai dengan keterangan yang menyebutkan bahwa masing-masing dari orang-orang ini diduga telah melakukan korupsi.

Praktik jurnalistik secara teknis dalam peliputan berita memiliki nilai berita. Agar berita memiliki nilai tertinggi ada empat faktor utama, yaitu ketepatan waktu (timeliness), kedekatan tempat kejadian (proximity), besarnya (size), kepentingan (importance) (Suhandang, 2004: 144-145). Contoh dalam hal ketepatan waktu, Harian Jawa Pos sebagian besar telah menerangkan akurasi waktu antara peristiwa dengan waktu terbit koran. Pada saat memuat berita, Harian Jawa Pos selalu memberikan tanggal kapan kejadian yang diberitakan tersebut berlangsung. Dengan begitu pembaca dapat mengetahui kapan berita 
itu di buat dan kapan berita di cetak. Harian Jawa Pos telah memberitakan secara jelas tanggal berapa waktu kejadiannya sehingga antara waktu cetak koran dengan peristiwa memiliki kedekatan waktu yang tidak terlalu jauh dan berita tidak dianggap basi.

\section{Penutup}

Penelitian dilakukan terhadap 16 berita pada Harian Kompas dan Jawa Pos periode bulan Januari tahun 2012. Hasilnya, dapat disimpulkan bahwa kecenderungan isi berita pada Harian Kompas adalah netral, bertele-tele, dan kurang lengkap dalam mengumpulkan data. Sedangkan Harian Jawa Pos, terlihat ingin memberikan semua kebenaran yang menyangkut kasus dugaan korupsi yang dilakukan oleh Anas Urbaningrum dalam kasus wisma atlet kepada pembaca.

Dalam pemberitaan mengenai kesaksian Nazaruddin, Harian Kompas hanya memberikan fakta bahwa Muhammad Nazaruddin gagal untuk datang ke sidang kasus korupsi karena sakit. Sedangkan Harian Jawa Pos lebih lengkap lagi dalam memberitakan tema ini, Harian Jawa Pos memberikan tambahan fakta bahwa kegagalan Muhammad Nazaruddin datang ke sidang telah menyebabkan tiga orang saksi kunci enggan memberikan kesaksiannya. Hal ini membuat fakta yang terungkap di sidang tidak sesuai dengan harapan masyarakat bahwa seharusnya nama-nama besar harusnya dapat terungkap dalam persidangan ini.

Pemberitaan mengenai kesaksian Yulianis, Harian Kompas menuliskan bahwa memang terdapat aliran dana ke pihak Anas Urbaningrum. Sedangkan Harian Jawa Pos menulis bahwa Hotman Paris Hutapea menuding Yulianis dan Jaksa Penuntut umum adalah pihak yang berusaha melindungi Anas Urbaningrum. Dalam pemberitaan mengenai status hukum Anas Urbaningrum, Harian Kompas mengunakan bahasa yang halus dalam memberitakan dengan tidak menyebut nama Anas Urbaningrum secara langsung tetapi lebih menggunakan nama secara umum yaitu kadre partai demokrat. Harian Kompas juga menulis bahwa sudah ada mantan kader Partai Demikrat yang telah menjalani hukuman karena telah terbukti di dalam persidangan melakukan tindak pidana korupsi.

$$
\text { Pada pemberitaan mengenai }
$$
kekuatan politik Anas Urbaningrum, Harian Kompas menulis bahwa kekuatan politik Anas saat ini sudah cukup untuk membuat dirinya tetap menduduki jabatan sebagai Ketua Umum Partai Demokrat. Sedangkan Harian Jawa Pos lebih tegas dalam menulis berita yaitu apabila memang Anas Urbaningrum sudah pasti terbukti terlibat kasus korupsi, maka Partai Demokrat akan segera mengganti dirinya dan mencari 
calon Ketua Umum Partai Demokrat yang baru.

Penelitian analisis framing ini kiranya akan semakin menarik bila peneliti lain hendak mengembangkannya dengan melihat variasinya dengan melakukan hal yang hampir senada. Terutama terhadap media lokal daerah di Indonesia. Penelitian juga dapat dikembangkan untuk menelisik lebih dalam bagaimana berita-berita politik media daerah mampu memberikan informasi. Pada akhirnya, informasi dapat digunakan untuk mengambil sikap terhadap isu-isu korupsi dalam konteks perpolitikan di Indonesia.

\section{Daftar Pustaka}

Bungin, Burhan. 2007. Penelitian

Kualitatif: Komunikasi, Ekonomi, Kebijakan Publik, dan Ilmu Sosial

Lainnya. Jakarta: Kencana.

Eriyanto. 2002. Analisis Framing;

Konstruksi, Ideologi, dan Politik

Media. Yogyakarta: LKIS.

Sobur, Alex. 2002. Analisis Teks Media :

Suatu Pengantar Untuk Analisis

Wacana, Analisis Semiotika, dan

Analisis Framing. Bandung: Remaja Rosdakarya.

Siregar, Ashadi, dkk. 1998. Bagaimana

Meliput dan Menulis Berita Untuk

Media Massa. Yogyakarta: Kanisius bekerja sama dengan $\mathrm{LP}_{3} \mathrm{Y}$.

Suhandang, Kustadi. 2004. Pengantar

Jurnalistik Seputar Organisasi,

Produk \& Kode Etik. Bandung:

Penerbit Nuansa. 
Jurnal komunikasi, Volume 6, Nomor 2, April 2012 